\title{
What's love (not) got to do with it. How to pair sexuality- and relationship research with citizen science.
}

\section{Stefan F. Ossmann \\ Department of Social and Economic History \\ University of Vienna \\ E-mail: stefan.ossmann@univie.ac.at}

Citizen Science is a powerful tool in many aspects, with the potential to change the world to the better. Some research topics are trendy or appear regularly, others are hard to find. And one aspect seems to be missing completely in this participative research approach: Relationship and sexuality. The following paper draws on the potential of citizen science in regards to sexuality research in general, and the long-omitted field of consensual non-monogamous relationships.

Austrian Citizen Science Conference 2020 - ACSC2020

14-16 September 2020

Vienna - Austria 


\section{Introduction: Relationship(s) and sexuality off the so-called "norm"}

Those readers who are clear that the title of the paper is based on the great song by Tina Turner from 1984 are right - and those who are not clear how emotions and sex can be linked with citizen science, and why this is of importance to society, are very welcome to continue reading:

"We want people no longer to see science no longer as an elite program, but as a process that affects all our lives (...). We (...) understand citizen science as a collaborative process through which new insights can be gained." (Heigl \& Dörfler, 2020). This quote of the self-image of citizen science recognizes not only that science affects "us" all, it also shows that "us" is not the academic elite only - and if one wants to spin the idea further, the "us" can be quite colourful. "Any discrimination based on any ground such as sex, race, colour, ethnic or social origin, genetic features, language, religion or belief, political or any other opinion, membership of a national minority, property, birth, disability, age or sexual orientation shall be prohibited." (European Union, 2000) is written in the Article 21 of the Charta of fundamental rights of the European Union - and is legally binding for member states since 2009. If we shine a spotlight on the last aspect, the article tells us that lesbian, bisexual and gay persons have, due to their sexual orientation, equal rights to heterosexual persons. In this fundamental EU legislation, no explicit references on gender identity, gender expression or sexual characteristics are included - which is the case in EU secondary law on non-discrimination, which explicitly refers to the term trans identity (Van den Brink \& Dunne, 2018, p. 8). A resolution on the rights of intersex people was adopted by the European Parliament in February 2019 - and this is where the anti-discrimination by legal bodies ends. While a current acronym as for example used by the organizers for the Toronto Pride Week in 2019, LGBTTIQQ2SA, ${ }^{1}$ claims to be much more inclusive, it still does not include everyone that does not consider themselves part of the heteronormative mainstream. It lacks the A for asexuality for example, and it does not include what the World Health Organization (WHO), in its latest ICD catalogue, ${ }^{2}$ calls paraphilic disorders, so for example people who practice intimate acts that fall into the BDSM acronym.

\section{Finding the blind spot: Consensual non-monogamy as the odd one out}

Also missing is a group that, individually, might or might not be the target of anti-discrimination laws, but which clearly is when considered as a group of more than two people: individuals in multiple, stable, permanent, consensual, non-monogamous relationships where intimate acts are

\footnotetext{
${ }^{1}$ The abbreviation for Lesbian, Gay, Bisexual, Transsexual, Transgender, Intersex, Queer, Questioning, 2-Spirited (indigenous North Americans, who fulfil a traditional third-gender ceremonial role), and Allies.

${ }^{2}$ The current version of the International Statistical Classification of Diseases and Related Health Problems (ICD) is ICD-11, for more information see (WHO, 2019).
} 
practiced - other than in the $18^{\text {th }}$ and $19^{\text {th }}$ centuries, when partnerships were based on romantic love, at present sexuality is integrated into the overall vision of a loving relationship (Eder, 2015, p. 538). It is not about cheating, also occasionally also found as infidelity, which is understood as one-night-stands, short affairs, secret relationships over a longer period of time - basically anything that involves sexual practices that are hidden and therefore not agreed by the main relationship partner, and in this sense non-consensual. It is also not about cruising, which stands for the “(...) purposeful search for a socio-sexual partner." (Bullock, 2004, p. 4), which involves no or only little emotions. It is about people who are in open relationships, typically characterized by couples who retain “(...) emotional intimacy within a primary relationship and pursue additional casual and/or sexual partnerships." (Levine, Herbenick, Martinez, Fu, \& Dodge, 2018, p. 1440); people who are in polyamorous relationships - defined as “(..) consensual relationship between more than two people based on emotional love and intimate acts over a longer period of time." (Ossmann, 2020, p. 363); ${ }^{3}$ and people who practice relationship anarchy: The (other than what one might assume when being confronted with the term) responsible and caring form of relationship with more than two persons involved - and the major difference to polyamory that romantic sex-based relationship hierarchies are completely rejected (De Las Heras Gómez, 2019, p. 2). To illustrate the matter, the following image shows how such a polyamorous relationship is perceived by an involved person.

\section{The potential power of citizen science}

While in contemporary Western society, sexual behaviors outside the norm were "once reserved for only the most brazen and adventurous of practitioners", consensual non-monogamy has recently become more visible to the general population (Scoats, 2019, pp. 2-3). And it is not a marginal phenomenon (any more), it is, for what we know at least for the United States, a constant across age, educational level, income, religion, region, political affiliation and race - with a wider variation when it comes to gender and sexual orientation (Haupert, Gesselman, Moors, Fisher, \& Garcia, 2017, p. 424). This short description reveals the challenge of generalizing the findings on research on Consensual Non-Monogamy: CNM-affected people are highly diverse, with different values, needs and levels of being 'out'. And this is where citizen science comes in:

With the power of many, and the understanding that every person can participate and is wanted for surveys, sexuality- and relationship research can become more representative. It has the

\footnotetext{
3 The idea for bringing Citizen Science and relationship- and sexuality research together developed from an Austrian Science Funds financed project where I - by the supervision of Prof. Dr. Franz X. Eder from the University of Vienna - compared self-perception of polyamorous living people with their media representation. For details please see https://polyamorie.univie.ac.at/en/
} 
potential to leave the rainbow-colored ivory tower and the social-media-bubble we usually recruit, deliver results from elder age groups we usually don't reach, allows access outside urban places to hear the voices of the countryside as well. Participants then can function as multipliers within their peer groups, recommending this surveys that can - depending on the concrete research question - follow qualitative (for example narrative biographical interviews) or quantitative (for example predefined questionnaires) approaches. A broader knowledge of the topic has the potential to reach individuals living such a love and life style without identifying with the term's polyamory or consensual non-monogamy. Furthermore, leaving the World Wide Web for pen and paper surveys means also to approach the non-digital natives ${ }^{4}$, and the ones that don't have the financial resources for the according equipment, or the interest in participating in computer-based polls.

\section{Summary}

Overall, the citizen science approach can make sexuality a topic to be talked about, non-hetero sexual orientation a behavior tolerated if not accepted; monogamy a concept questioned without giving it up or demonize it. When talked about, it can lead to satisfied intimate relationship, therefore being an important part of physical and psychical wellbeing. It can help the young to distinguish their own sexuality from media-transferred porn utopias, it can tear down longexisting hierarchies, it can legitimize and empower female sexuality. Citizen science can bring sexuality- and relationship research from the edge of society right into the center. And from there back to the people. Or as John Lennon has put it more than a decade before Tina Turner: Power to the people!

\section{References}

[1] Bullock, D. (2004). Lesbian cruising: An examination of the concept and methods. Journal of Homosexuality, 47(2), 1-35. doi:10.1300/J082v47n02_01

[2] De Las Heras Gómez, R. (2019). Thinking Relationship Anarchy from a Queer Feminist Approach. Sociological Research Online, 24(4), 644-660. doi:10.1177/1360780418811965

[3] Eder, F. X. (2015). Popular Sexual Cultures in Western Europe (1930s to the Present). In J. D. Wright (Ed.), International Encyclopedia of the Social \& Behavioral Sciences (2 ed., pp. 533-539). Amsterdam: Elsevier.

[4] Haupert, M. L., Gesselman, A. N., Moors, A. C., Fisher, H. E., \& Garcia, J. R. (2017). Prevalence of Experiences with Consensual Nonmonogamous Relationships: Findings from Two National Samples

\footnotetext{
${ }^{4}$ The term digital native is used in communication science for all individuals born 1980 or later that are assumed to handle digital communication devices by native manner.
} 
of Single Americans. Journal of sex \& marital therapy, 43(5), 424-440. doi:10.1080/0092623X.2016.1178675

[5] Heigl, F., \& Dörfler, D. (2020). About Österreich forscht. Our vision. Retrieved from https://www.citizen-science.at/en/about

[6] Levine, E., Herbenick, D., Martinez, O., Fu, T.-C., \& Dodge, B. (2018). Open Relationships, Nonconsensual Nonmonogamy, and Monogamy Among U.S. Adults: Findings from the 2012 National Survey of Sexual Health and Behavior. The Official Publication of the International Academy of Sex Research, 47, 1439-1450. doi:10.1007/s10508-018-1178-7

[7] Ossmann, S. F. (2020). Introducing the new kid on the block: Polyamory. In Z. Davy, A. C. Santos, C. Bertone, R. Thoreson, \& S. Wieringa (Eds.), Handbook of Global Sexualities (Vol. 1, pp. 363385). Thousand Oaks, CA: SAGE.

[8] Scoats, R. (2019). Understanding threesomes: Gender, sex, and consensual non-monogamy. London, New York: Routledge.

[9] European Union (2000). Chapter of fundamental rights of the European Union. Brussels Retrieved from https://www.europarl.europa.eu/charter/pdf/text_en.pdf

[10] Van den Brink, M., \& Dunne, P. (2018). Trans and intersex equality rights in Europe - a comparative analysis. Brussels: European Commission Retrieved from https:/ec.europa.eu/info/sites/info/files/trans_and_intersex_equality_rights.pdf

[11] WHO. (2019). ICD-11. International Classification of Diseases 11th Revision. In. Geneve: World Health Institution. 